\title{
エアード氏法による各種脳疾患の胛波に関する研究
}

（本淪文の要旨は第4回日本兴波学会に於て発表した）

\author{
第 2 編 \\ エアード氏法による脳腫瘍及びその他 $2 ， 3$ の脳疾患の脳波につんて.
}

岡山大学医学部第 1 (阵内) 外科呚室（指導，陣内敉授)

副手稻垣郎

〔昭和 31 年 9 月 5 日受稿〕

目次

第 1 章 緒言亚江文献

第 2 章 予備実験

第３章 検查方法及び検查対象

\section{第1章 緒言並に文献}

最近脳外科の進步けめざましく，その治瘾 成績も年ととすに良好となつている，Godlee 35)36) が正しく診断された最初の脸聥瘍剔出 術を行つたのは1884年であつて，さほど古い ものではない. 以来 Nacewen ${ }^{35 !}$, Horsler ${ }^{35) 37),}$ Krause $^{35)}$ ，Bergmann ${ }^{35)}$ 等㳖より欧洲飞打い てその基礎が開拓されたが，近代脳外科が確 立されたのは専ら米国における Cushing ${ }^{35) ;}$ Dand $y^{35}$ ，Bailey ${ }^{35)}$ 等の晹である。

兴腫塌はあくまて外科的治療を加えなけれ ば治瘾せしめることのできないすのであり， それには術前に腫瘍の種類とその位置を正確 飞診断することが先決問題であり，またもつ と重要な問題である。

Hughlings Jackson ${ }^{35)}$ は両側の 血乳頭及 びその他の著明な缠曒症状を呈した例で剖検 により軽徵な脳の充血を証明した以外飞何等 腫激らしきものを認め得なかつたことを記载 して扣り，また Eichhorstは獎液性脳朕炎が 時として盾湶類似の症状を呈する事実を数例

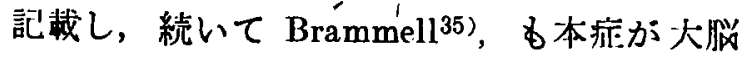
又は小䒇腫湯と全く同一の症状を呈しうるこ とがあるのを認めた．このように脳腫瘍以外 の疾患がしばしば腫㾕類似の症候を呈するこ
第 4 章 記録の判定及び愉査成纃

籍 5 章 総括业に洘按

第 6 章 結 諭

とは枚挙に遑のない俆どで，このことからす

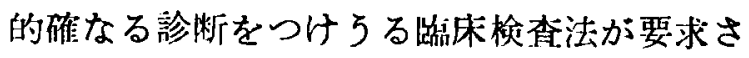
れてくるのである，とくに外科的治療を加充 んとする時には局所診断がその出発占になる のであり，我々の診断的努力の大部分はこれ に注がれるのである.

前編にても述べたごとく, 初め単に生理学 上の一つの研究として出発した脳波は Gibbs

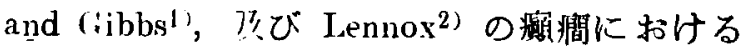
異常脸波の報告によりその臨床への道がひら け，次で，Waller による脳腫掦の異常波の

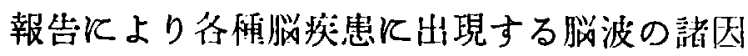
子が諸家の注目するところとなつたまた一 万では Dandy ${ }^{35}$ とよる気脳室撮影術, INoniz による脳血管撮影法などの応用により，さ らに今日超音波，放射性：同位元䋈の利用によ つて脳電焙の診断法は一段の進歩をとげつつ ある現況にある。しかしながら，患者に苫痛 を与えない利点のみによつても，脳波のこの 栝の俭査の5ちで占める地位は特別なものが ある.

本編では脸腫瘍の他飞脳軟化症及び脳挫傷 をる含んでいるが，これらも脳波上からは本 質的飞脳腪瘍と同様な所見を示すのでこれら を一括してのべることとする。 


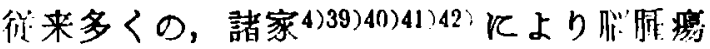
の患者ではその多くが脳波に異常をしめすと いわれているが，これらの報告を総括すると

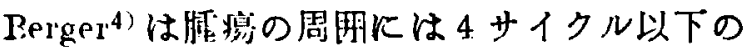
徐波が存在すると述へ，これは振门の增大を 伴つていて，明らかに異常波であることを見 出し，これを $\delta$ 波とよんだのは周知の通りで ある。

彼はこの徐波は喱游附近の神経細胞の正常 代謝飞必要な条件が腫㾂によつて妨害を受け るために発生するるのと耉えた。すなわち成 長しつつある新生物により血管を压迫され阴 血，整血，血行停止，ときには血腋細胞の

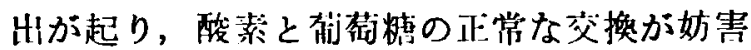
され，そのためにこれらの脳細胞の正常電気 活動が障碍を受けるというのである。

また，も5一つの要素は腄埝により視床に ある正中線深部の細胞集団からの，あるいは 他の皮質中枢からの絬合が中断されることで ある。このために細胞性電気活動の翼常な同 期化が促進され，振巾の大きい徐波が作り出 されるのであるうと述べている.

腫瘍から 6〜 $7 \mathrm{~cm}$ はなれた脳細胞の循環や 代謝が障碍を受けない部になると脸波は正常 である4)，また腫瑒が頭蓋直下に存する場合 は皮質を压迫して頭蓋より嗃ざけるために正 常の頭皮上のリズムを㧕制し減衰せしめ，そ のために脳波はあきらかな電圧の非相称性， あるいは電気的活動のない電気的無言 (electrical sjlence）をさえ示すときるある. 往々脳 腫㿑飞伴万兴水腫による異常波は上飞述へた るのと異なり低電压と正常時飞見られる基本 波（ $\boldsymbol{\alpha}$ 波）の消尖とが全作飞見られる2)。こ れ以外には特別なものはないとされている。

これらの波形，電压の変化以外飞, Wal-

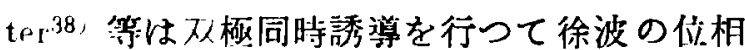
の逆転飞特別な意義を認め，䉓場的飞みてそ の逆枟部位がその徐波の発生部位であること を明にしている。

これら脳腫痬の異常波に関する㷋来の報告 を見ると，多くは疗例の報告にとどまり，こ れを総括して格討した報告は少く，要するに
脳腫場の愍波はあくまでも徐波のみであり，

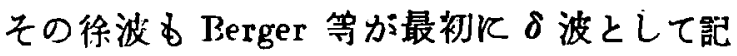
载した 4 サイクル以下のるのにとどまらず 5〜6〜7 サイクル附近のすのも含まれて和り， たまたま幸連な場合にその位相の逆転や，異 常波の㧧弱因子により局所診断が得られると いう程度である。

しかし，今日この脳波す前述の如く必ずし も有力なものではなく，さらに精度の高い誘 導法や記録判定の基準が要求されているので ある。

元来脸波には双極, 単極誘導の 2 法があ り，双極誘導には程々の利点があり，上述の Walter 等により早くから脳腄瘍診断に対す る双極誘導の洒值が述へられていたが，これ は主として位相を注目するのが主であり，波 形の剧所的差異についてはふれていない。そ して今迄主として単極誘導が臨休上に使用さ

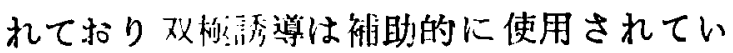
た.

さらに兴波には，前編に扔いて述べだと く個人差が相当見られるるのであり，軽度の 異常の判定にあたつてその異常の発見率飞大 きな差を生ずることは当然考えられるところ である。そしてこの対照としては被検者の正 常時の脳波をとることが最す良いわけである が，これは不可能なことである。しかし幸い 同一人の左右対称部の頭皮上より誘道された 䋞波は正常人ではきかめてよく一致している ことが認められている1)21.

㗓つて我々が脳波の正常, 異常を判定する 場合，むし病変が一側のものとすればその対 側を対照とすることにより従来の判定の成縝 をはるか问上せしめることが可能となって くると腾克られる。

さいわい，我々外科領域で取扱了脳疾患て はその病変の限局されたるのが多い，従つて 私忙この们所的美異飞重点を置いた特別な工 アード氏法による双極誘導法を用いて脳腯境， 股、軟化症，㨫挫傷等の患者の㨫波をとり，そ

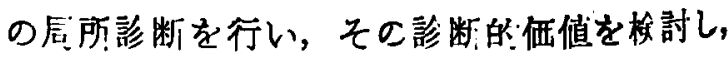

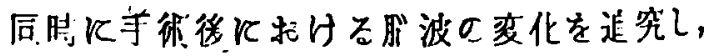


本法が治㙩効果の判定に役立つか否かを検討 する目的をるつて本研究を行つた。

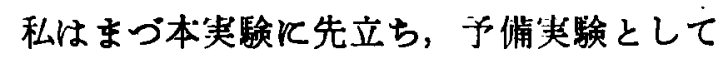
この脳腫境の際に見られる徐波の週期の釉曲 をさらに確かめるため，次にのべるよな動 物尖験を行つた。

\section{第2章予借実監}

脳腫煌の場合にあらわれる脳波的変化，一 なわち徐波の邀期の筑囲を知るために，私は 10例の成犬を用いで予借䒠験を行つた。

笑験に括ける手術操作は無国的にこれを行

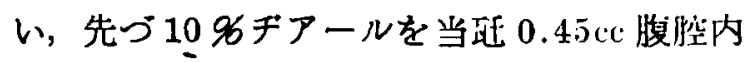
飞注入晽醉し，チアール投与後 3 時間以上経 過して、すなわちチアールによる速波の消失 後脳波を記録するごとく一定した。

手術前の脳波記録後開頭し硬膜下に $5 \mathrm{~mm}^{3}$ 大のラミナリア片を扦入し硬膜を絴合閉鎖し た. 術後 1 日目は全例とも自動運動も反射運 動も弱く，呼吸も小さく弱つているが; 術後 2 日目には反対側四肢の晽愺を呈してはいる が一般状態が恢復してくるので，この時期に
脳波を記録した。

いま術前，術後の脳波を示せば第 1 汹の如く である。

すなわち，ラミナリア挿入側においては， 6〜7サイクルの徐波と同時に 3〜5サイクル の徐波を明認めるが，反刘側飞打いては 6〜7サイクルのbののみで, 3〜5サイクル

図 (1)

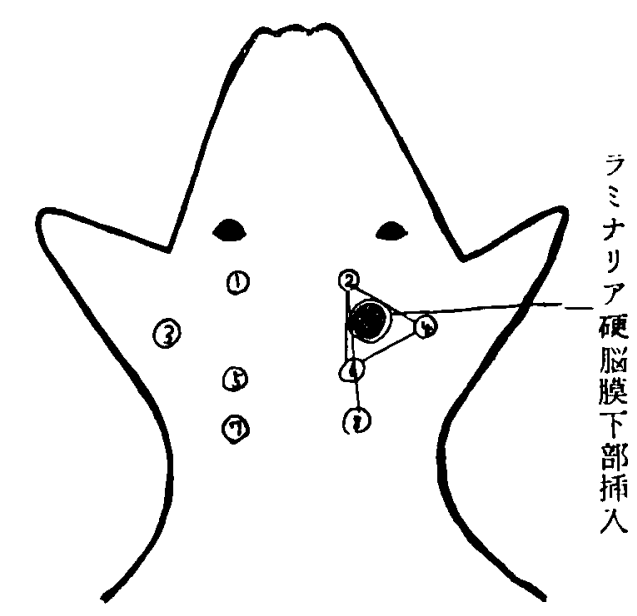

$1-3<\triangle \quad 1-5-\triangle \quad 1-7<\triangle$ $3-5<\triangle$

$$
\begin{array}{ll}
\text { 図 (1) } 2 & 1-3 \\
\text { 術犬 } & 2-4 \\
\text { 前 } & 1-5 \\
& 2-6 \\
& 1-7 \\
& 2-8 \\
& 3-5 \\
& 4-6
\end{array}
$$

図 (1) $3 \quad 1-3$

$$
\begin{aligned}
& \begin{array}{ll}
\text { 術 犬 } & 2-4 \\
\text { 姼 } & 1-5 \\
2-6
\end{array} \\
& 1-7 \\
& \text { 2-8 } \\
& 3-5 \\
& 4-6
\end{aligned}
$$
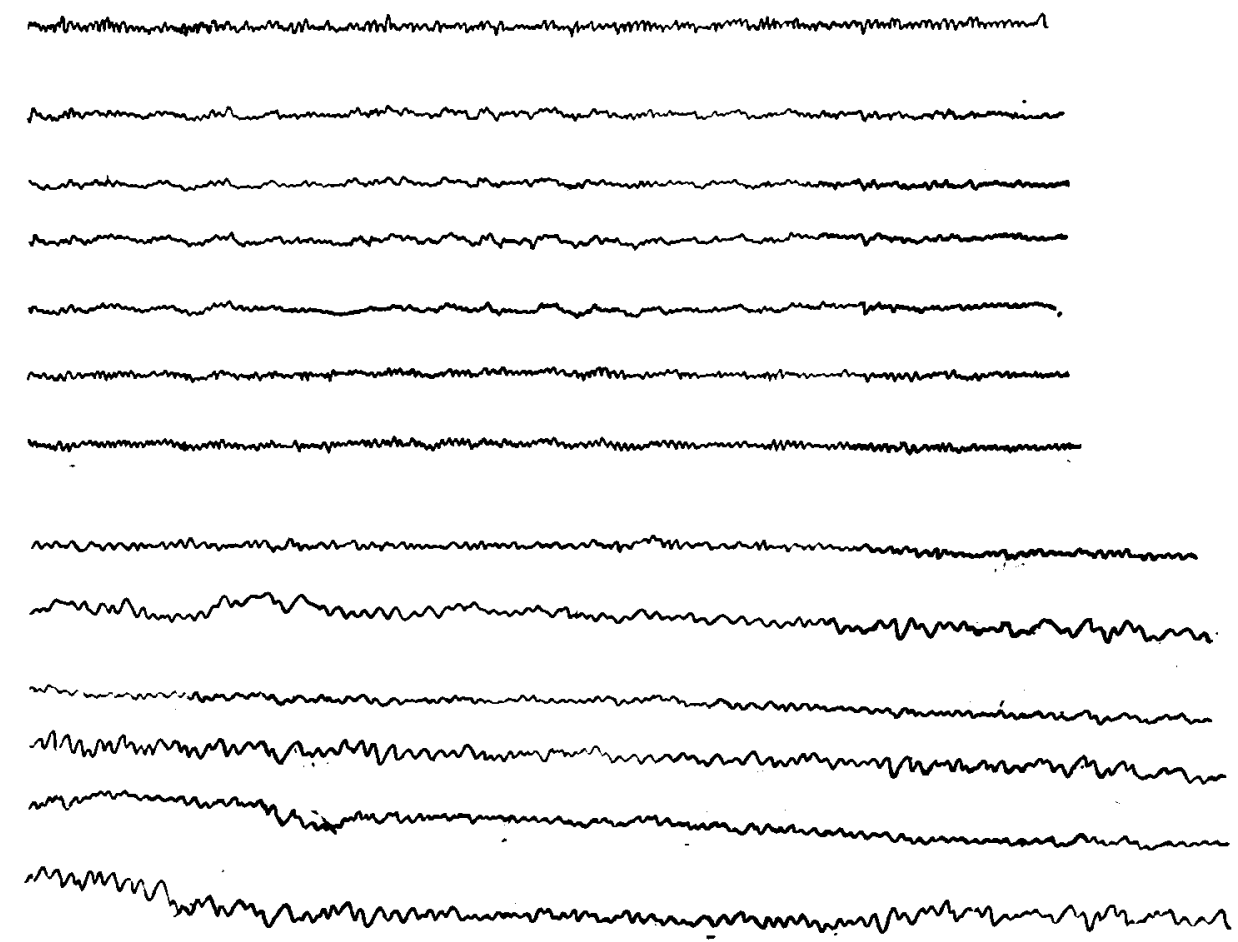

mann 
の徐波を認めない。

以上のことから腫境そのるのによる徐波は， 3〜5サイクルのすのが基本型であり，これに

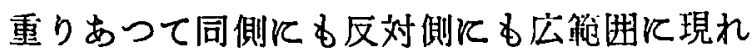
る振巾の大なる6〜7サイクルの徐波は浮腫に
因するものであると思われる。

\section{第3章 检查方法並に检査対象}

記録装置，電極，記録方法等は前編飞述一 たと全く同棁である.

\begin{tabular}{|c|c|c|c|c|c|c|c|c|}
\hline 氏 & 名 & 性別 & 年令 & 病 & $\begin{array}{l}\text { 胹波による } \\
\text { 局听診断 }\end{array}$ & {$\left[\begin{array}{l}\text { 術前 敛 } \\
\text { 波听 見 }\end{array}\right.$} & $\mathrm{X}$ 線 所 見 & 㯲後畄 \\
\hline 藤 & O & $\hat{\delta}$ & 13 才 & 右頭頂部血管腫 & R. $\mathbf{P}$. & $6.7 .9 . \mathrm{cps}$ & 右脳室拡大变形 & 679 \\
\hline 町 & $\mathrm{O}$ & $\hat{o}$ & 9ł & 左側頭部ブサモーム・ & L. T. & 7.9. cps & 左側頭部石炏沈着像 & 9. $\stackrel{c}{c}$ \\
\hline 早 & 0 & 우 & 60 才 & $\begin{array}{l}\text { 右前頭一側頭部エンドテ } \\
\text { 部 }\end{array}$ & R. F-T. & $\mid \begin{array}{l}3.4 .6 .7 .8 \\
9.10 . \mathrm{cps}\end{array}$ & 右脳室は任迫され饻形 & 8. cps \\
\hline 小 & O & $.9+$ & 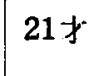 & 頭莣咽頭腫 & 不 明 & 3.4.5.cps & $\begin{array}{l}\text { 上ルコ鞍部变形不 } \\
\text { 着像 }\end{array}$ & $\begin{array}{r}7.8 .9 \\
\text { cps }\end{array}$ \\
\hline 高 & $\mathrm{O}$ & $\hat{\delta}$ & 21 才 & 頭蓋咽頭腫 & 不 明 & 6.7.9.cps & $ト ル ル コ$ 鞍部公形 & 7.8.9. \\
\hline 木 & 0 & 우 & 22 才 & 左聼神経神経ノイリノー & L. 0 . & 6.7. cps & 左脳室抬大 & 9. cps \\
\hline 森 & 0 & $\hat{\delta}$ & $24 才$ & 左頭頂部血管腪 & L. P. & 6.7. cps & 左脳室呟大変形 & 6.7. cps \\
\hline 山 & $\mathrm{O}$ & $\hat{\delta}$ & $26 才$ & $\begin{array}{c}\text { 右前頭畄底部オリコ } \\
\text { トロク }\end{array}$ & R. F. & 5.6. cps & $\begin{array}{l}\text { 右脳室任迫により左方 } \\
\text { 飞偏矽 }\end{array}$ & 7.8. cps \\
\hline 藤 & O & $\hat{o}$ & $13 才$ & 頭蓋、咽頭腫 & 不 明 & 7. cps & トルコ㜞部公形 & cps \\
\hline x: & $\mathrm{O}$ & $\hat{\delta}$ & 48才 & 頭蓋咽頭腫 & 不 明 & 7. cps & トルコ鞍部变形 & 8.9. cp \\
\hline 堀 & 0 & $\hat{\delta}$ & $37 才$ & 左聴神経ノイリノーム & -L. $\quad$ o. & 6.7. cps & 左脳 & 8. \\
\hline 佐 & $\mathrm{O}$ & 우 & 65 才 & 松 果 腺 腫 & 不 明 & 6.7. $\mathrm{cps}$ & トルコ鞍部变形 & \\
\hline 早 & 0 & $\hat{\delta}$ & 23 才 & 右聴神経ノイリノーム & R. 0. & 9. cps & 右側脳室後角変形 & 9. cps \\
\hline 片 & 0 & 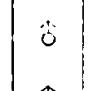 & $42 \succ$ & リゴテントロ & R. T. & 6. cps & 右腷室厸人齐形 & 9. \\
\hline 石 & O & o & 4 & 脸下垂体 & 不 明 & 9. cps & トルコ鞍部変形 & 9. cps \\
\hline 大 & 0 & $\hat{o}$ & $47 \Varangle$ & 左後頭蓝富真珠腫 & L. 0 . & 12. $\mathrm{cps}$ & 左後頭部石灭汍 & 12. $\mathrm{cp}$ \\
\hline 柳 & O & $\hat{\mathrm{s}}$ & $30 \nvdash$ & 右前頭ア゙ストロチトーム & R. F. & 9. cps & 右脳室前角変形 & 9. $\mathrm{cps}$ \\
\hline$\equiv$ & 0 & s & $10 \mathrm{r}$ & $\begin{array}{l}\text { 部チリオフラ } \\
\text { チフォルメ }\end{array}$ & L.F-P. & 4.6. cps & 左脳室玨迫され忿形 & \\
\hline 神 & 0 & $\delta$ & $63 \mathrm{~s}$ & 右前頭-側頭部脳軟化症 & $\mathbf{R}$ & $\begin{array}{r}6.7 .8 .9 \\
\mathrm{cps}\end{array}$ & $\begin{array}{l}\text { 存前 } \\
\text { 慧脳 }\end{array}$ & $\begin{array}{r}6.7 .8 .9 . \\
\text { cps }\end{array}$ \\
\hline 巻 & 0 & $\hat{o}$ & 58 ґ & 左側頭-頭丁 & L. T-P. & 6. cps & 拉入紧帅 & \\
\hline$=$ & $\mathrm{O}$ & 우 & 50 & 右:内 & L. ? & 7.9. $\mathrm{pps}$ & 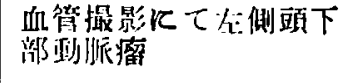 & 7.9. $\mathrm{cps}$ \\
\hline$\%$ & 0 & 우 & $35 \nsucc$ & 杬溯顽部メニンギオーム & R. F. & 7.9. cps & 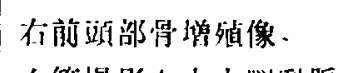 & 9. $\mathrm{cps}$ \\
\hline 䇴 & 0 & $\hat{\delta}$ & .51 丸 & 左側豆 & $\mathbf{L}$. & ps & 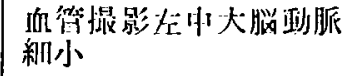 & cps \\
\hline 藤 & 0 & 우 & $7 x$ & $\begin{array}{l}\text { 左後頭泴エペンデイモー } \\
\text { 作 }\end{array}$ & L. $\quad$. & 4.5. cps & 左脳室後角変形 & \\
\hline 開 & 0 & $\hat{\delta}$ & $13\}$ & 右頭媔部血管腫 & R. P. & $\begin{array}{r}\text { 6.9.10. } \\
\text { cps }\end{array}$ & 右脳室拡大 & 9. cps \\
\hline 井 & O & $\ddot{\circ}$ & $46 \nsucc$ & 左槙神狂ノイリノー二 & $\mathrm{L}$. & $7.8 .9 . \mathrm{cps}$ & 左脳室後角变形 & 9. $\mathrm{cps}$ \\
\hline 縕 & O & $\hat{\sigma}$ & 34 才 & モアンギオ & R. P-O. & 9. cps & 右側脳室拡大後角変形 & 9. cps \\
\hline 安 & 0 & $\hat{o}$ & $7 \Varangle$ & 左側頭部脳挫笩 & L. T. & 9. cps & 左側頭部頭蓋骨折像 & 9. cps \\
\hline 濑 & 0 & $\hat{o}$ & $28\}$ & 右側頭蔀脳挫偤 & T. & 9. $\quad$ cps & 右側頭頭盐骨折像 & 9. cps \\
\hline 相 & 0 & $\hat{\delta}$ & $33 \%$ & 志頭江䇉脳挫侮 & L. P. & 6. eps & 左頭泊部頭篮骨折像 & 9. cps \\
\hline
\end{tabular}


電函の刺入部位により被検者が疼痛を覚え， また恐怖におびえ顔面筋を動かすようなとき には，筋からの動作電流が混入して，脳波が 得られないので一時中止し，電極の位置を少 し変えねばならない。

検查対象：脳腫場 24 例, 脳軟化症 3 例, 脳挫傷 3 例で合計30例である.

\section{第4章 記録の判定及び检查成績}

〔1〕記録の判定：本法による判定基準を 示すと次の如くである.

(1) 徐波: 前述のごと 徐波については 5 サイクル以下のものと，6サイクル以上のる のとを区別する必要がある．いま左右対称部 位を比較する際，サイクルの小なる側を病側 として記载する，速波数が等しい場合には振 巾の大なる力を病側とする。この場合1〜3が 2〜4より徐波の変化が大なれば，とくに5 节

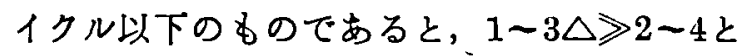
記載する。

また 6 〜 サイクルのすのであれば, 1〜3 $\triangle>2 \sim 4$ と記载する。

(2) $\boldsymbol{\alpha}$ 波の振巾の离低：脳波の $\boldsymbol{\alpha}$ 波が著明 飞低䉓死を示す部位があれば，これを障的部 位であると見る。また高䉓庄を示寸部位があ
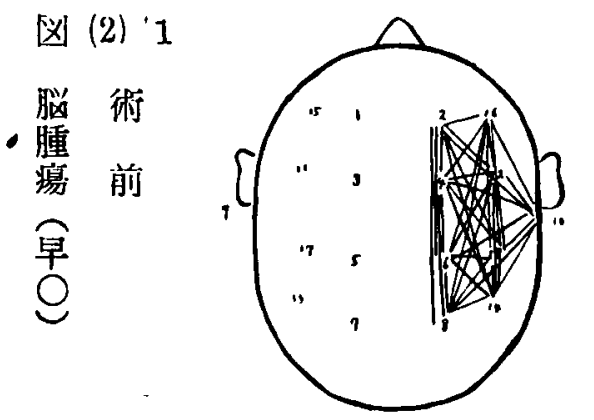

$$
\begin{aligned}
& 1-3 \ll \triangle \quad 3-13>\quad 7-15<\triangle \\
& 1-5<\triangle \quad 3-15 \therefore \quad 7-17 \triangle \\
& 1-7<\quad 3-17<\triangle \quad 9-11<1 \\
& 1-9<\triangle \quad 5-7>\quad 9-13< \\
& 1-11 \ll \triangle \quad 5-9<\triangle \quad 9-15 \leqslant \triangle \\
& 1-13=5-11<\Delta \quad 9-17=\triangle \\
& 1-15<\Delta \quad 5-13<\triangle \quad 11-13<\Delta \\
& 1-17 \div \triangle \quad 5-15 \leqslant \Delta \quad 11-15 \div \Delta \\
& 3-5 \ll \quad 5-17 \leqslant \quad 11-17 \ll \triangle \\
& 3-7>\quad 7-9 \ll \triangle \quad 13-15 \leqslant \triangle \\
& 3-9 \ll \triangle \quad 7-11 \therefore \quad \therefore \quad 13-17<\Delta \\
& 3-11 \leqslant \triangle \quad 7-13 \quad 15-17 \leqslant
\end{aligned}
$$

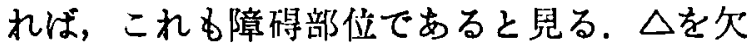

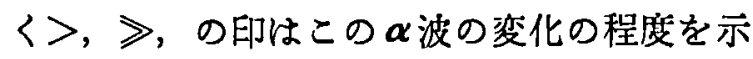
す.

（3）位相の逆転：位相の逆転を認めた部位 を障碍部位であるとする.この際特別な記号 は用いずに記録用紙に部位を記入する。

例えば 1〜3:3〜5 の部位相の逆轱を見 ると言5具合飞記入する。

\section{〔2〕検查成䋶〕}

腫湯，軟化症，挫鹪合計30例の患者飞つい て本法による脳波検查を行い，その5ち局在 の決定が可能であり，手術所見と一致したる のは24例であり，全体の80\%である.

局在の決定が不能であつたものは 6 例で全 体の20\%である.この 6 例中 5 例は脳下垂体 部の腫韵，他の 1 例は松果腺腫であつた. す なわちこれらの正中線上に生じた腫煬例を除 けば 100 名に怙いて局所診断が可能であつ た.

術後の記録に括いては，腫焬が完全に剔出 できて臨床症状の好転したものにおいては異 常波が消失して脳波は正常飞復している.

全症例を一括して示せば第 1 表の如くであ る、いまその5ち第 3 例, 第23例の脳波所見 を示せば第 2 汹，第 3 図の如くである.

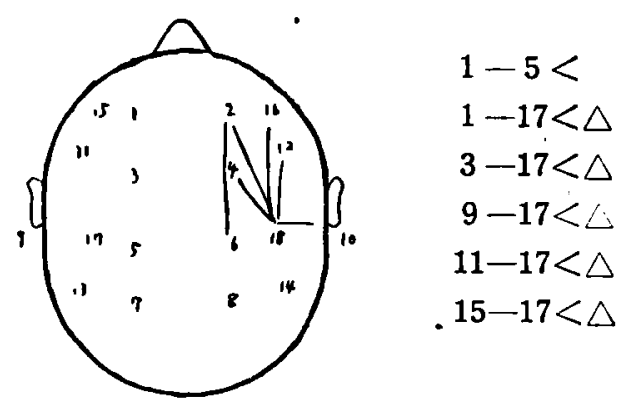

18 (postcentralis) を中心としで唒度に。 浮腫が存在する。 
図 (2) 2 lon

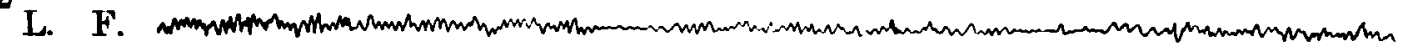
R. F. MWW
L. AT.
R.AT.
L. P.

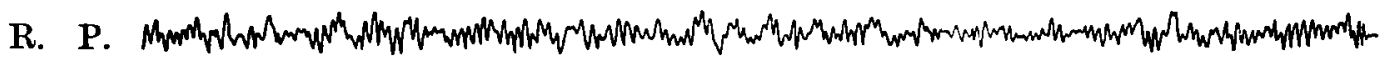
L. $\mathrm{O}$.

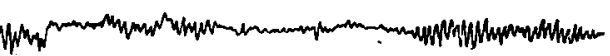

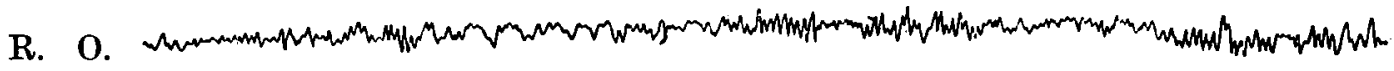

図 (2) 3

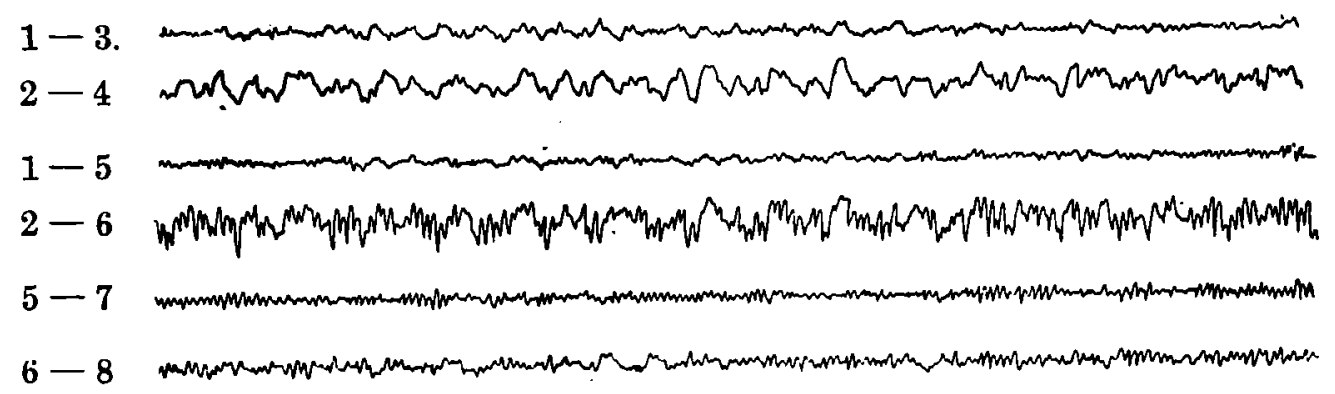

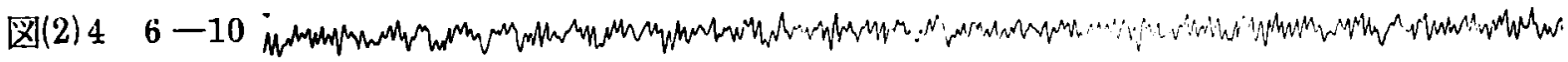

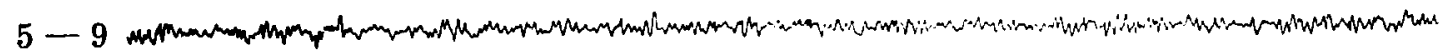

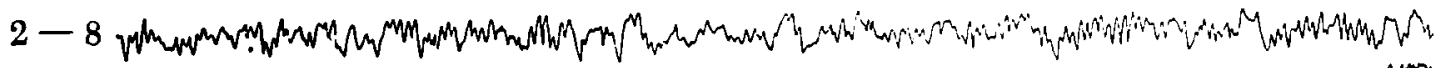

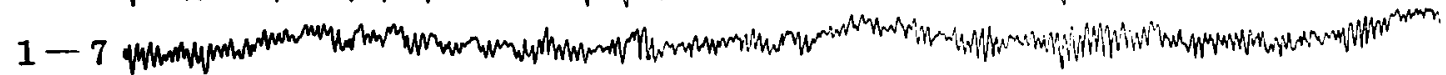

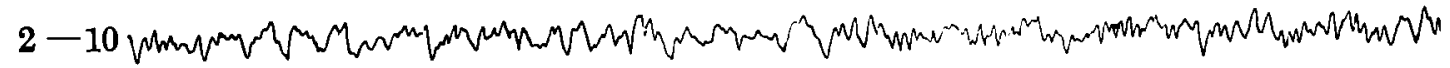

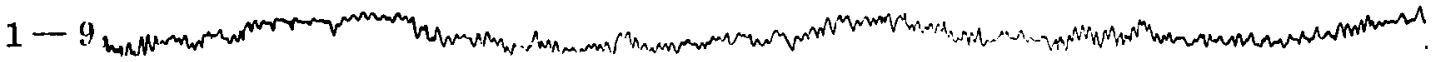

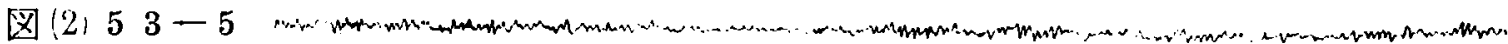

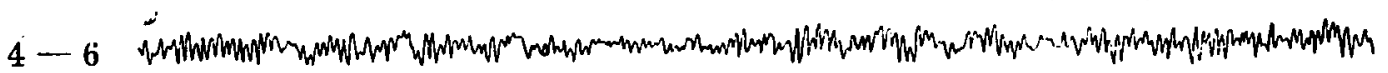

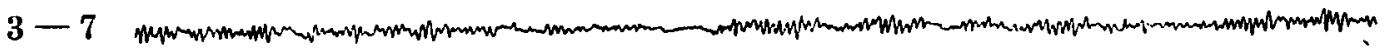

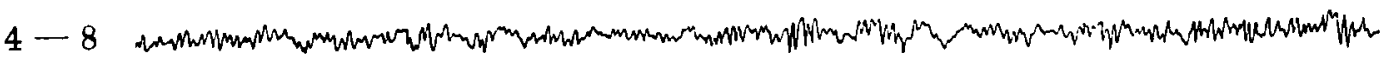

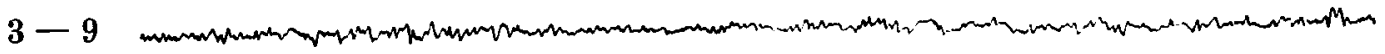

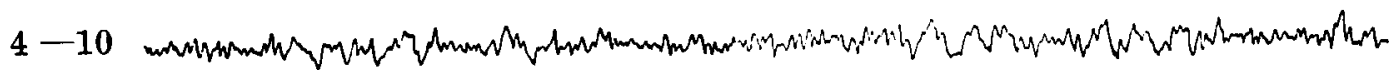

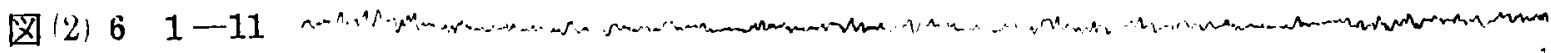

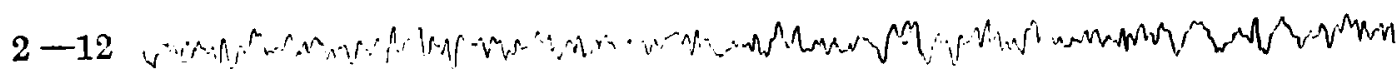

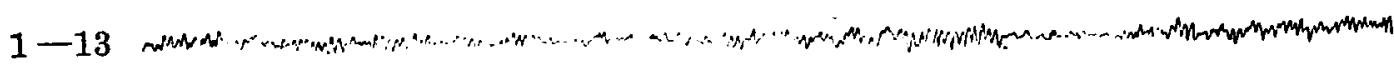

2-14 Prow

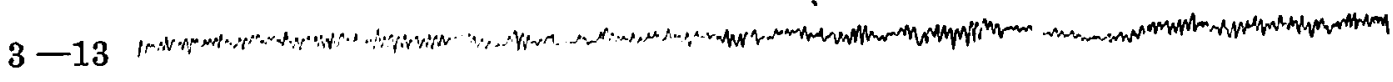

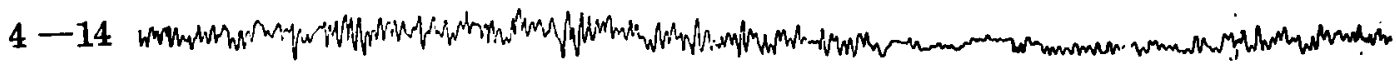




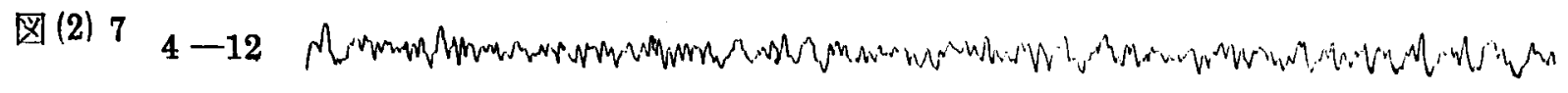

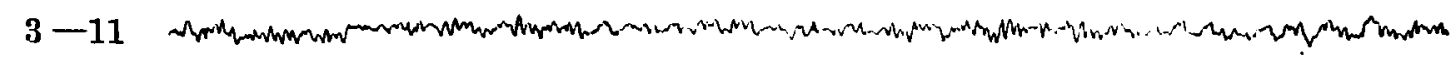

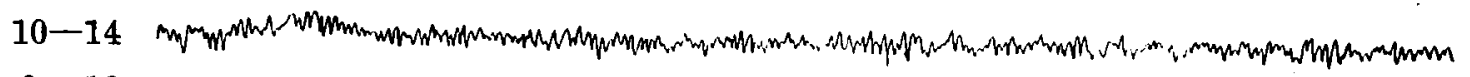

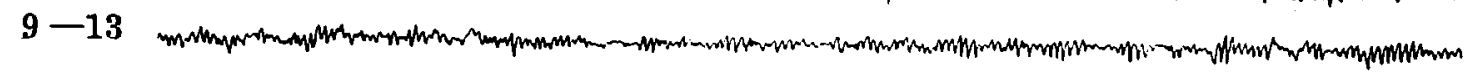

$10-12$

$9-11$

园 (2) $8 \quad 6-12$ r

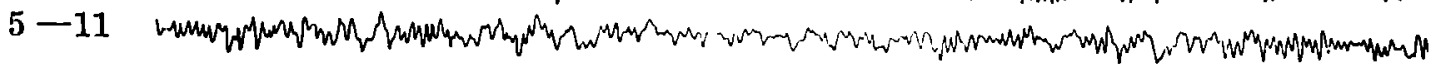

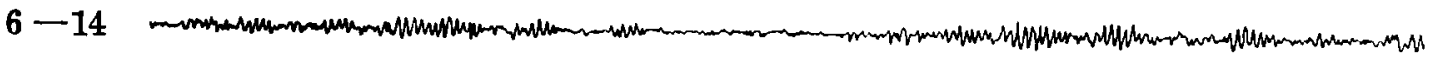

$5-13$

$8-12$

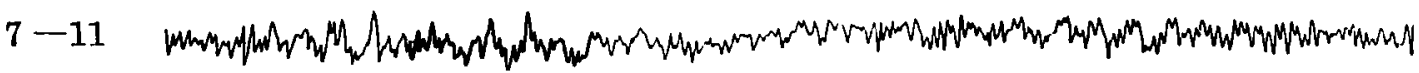

図(2) $9 \quad 7-13$

$8-14$

$11-13$

$12-14$

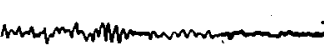

-

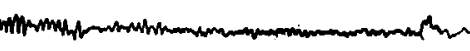

$7-9$

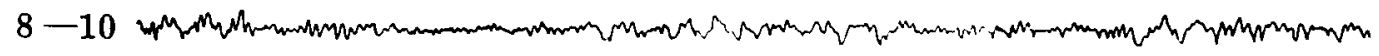

国 (2) 10 9-15

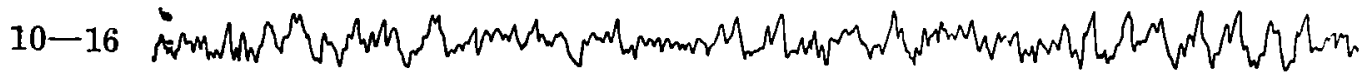

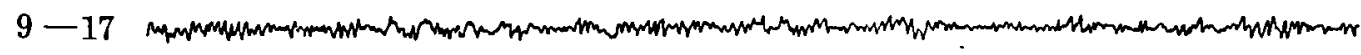

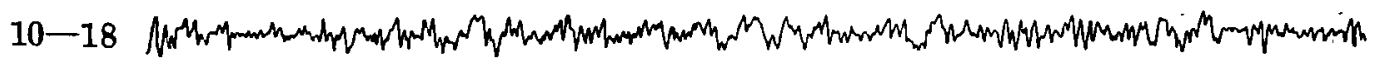

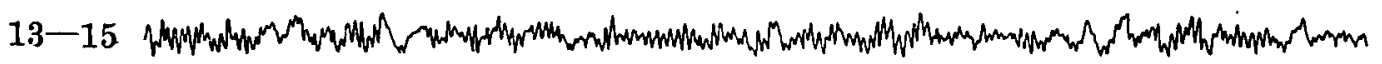

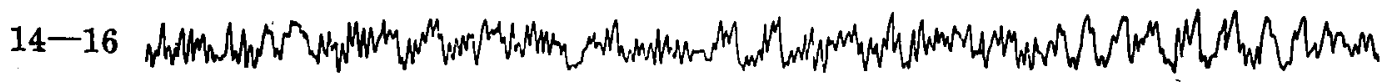

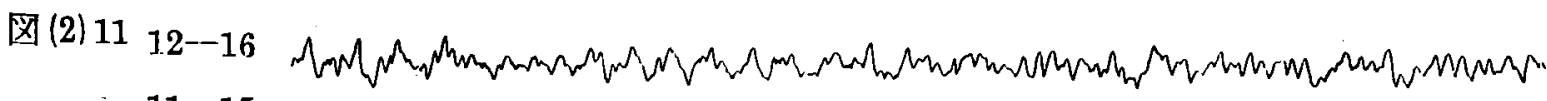

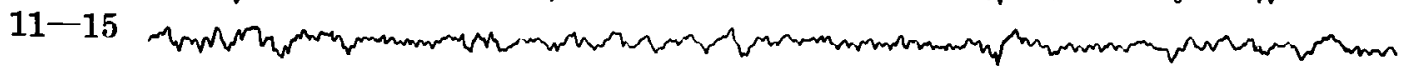

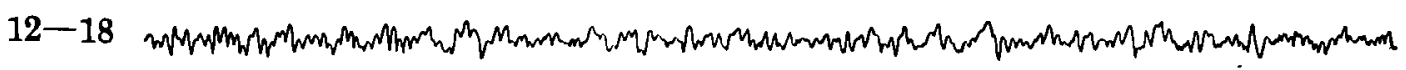

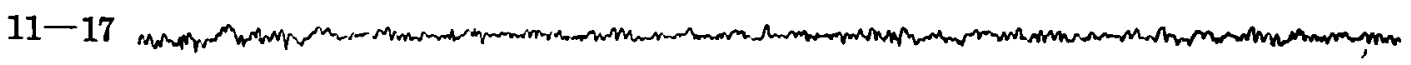

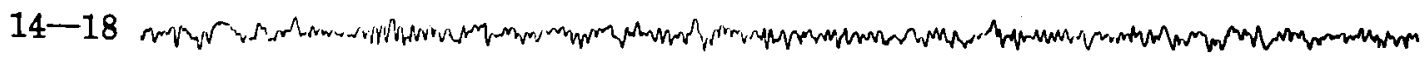

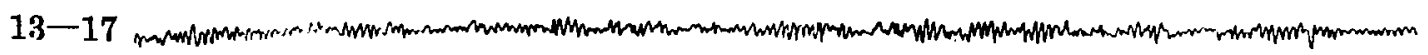




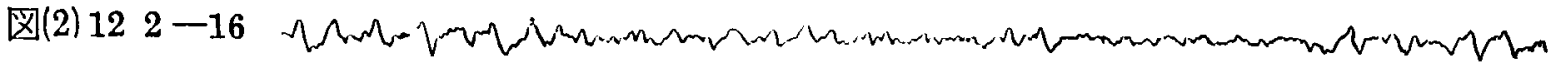

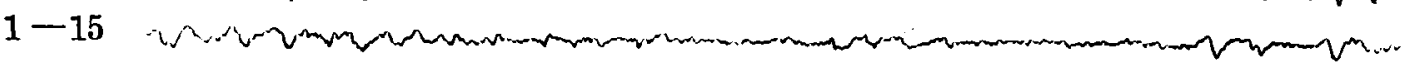

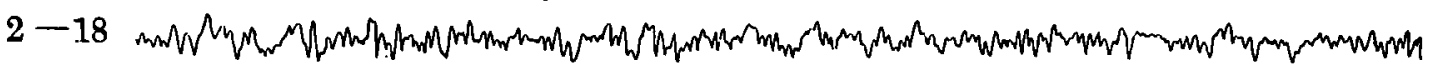

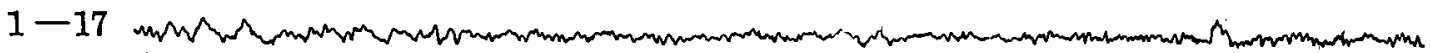

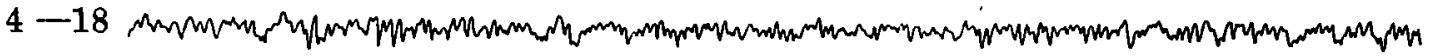

$3-17$

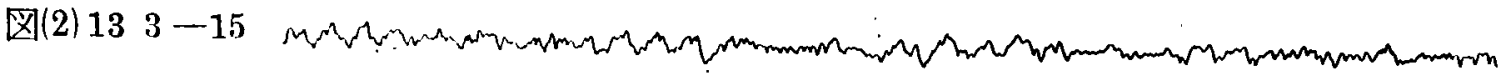

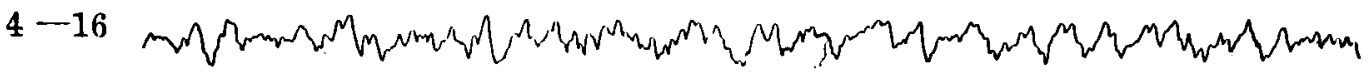

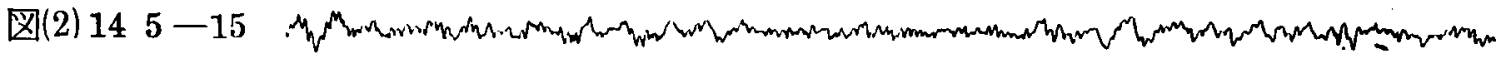

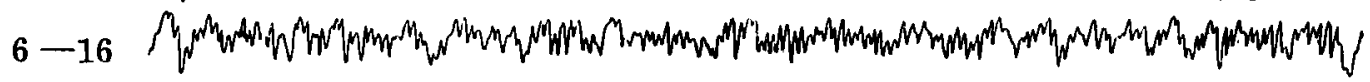

$5-17$

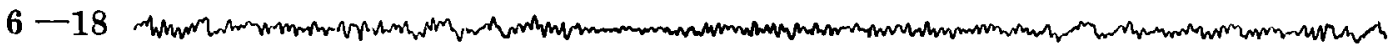

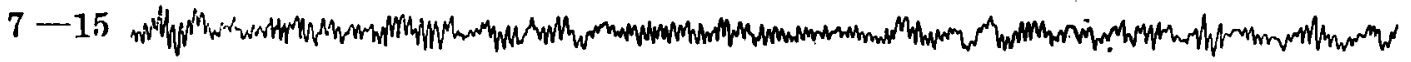

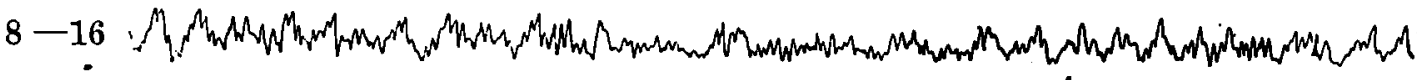

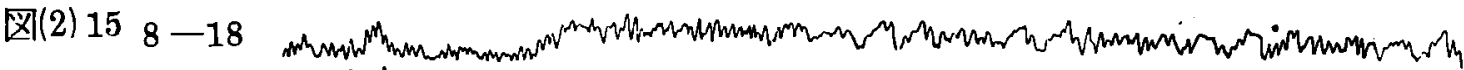

$7-17$

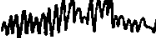

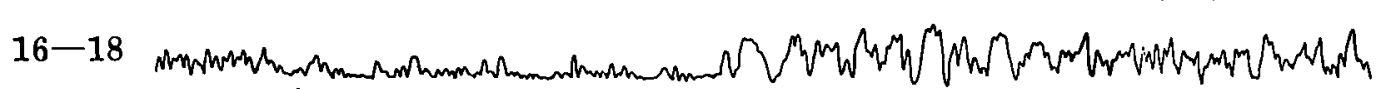

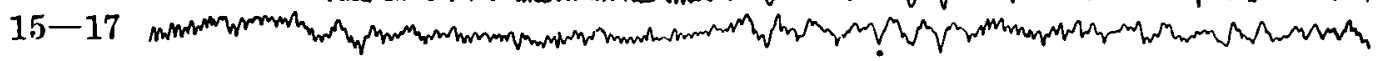

図(2) 16 L. F. Ime T

術後

R. F.

L. AT.

R.AT.

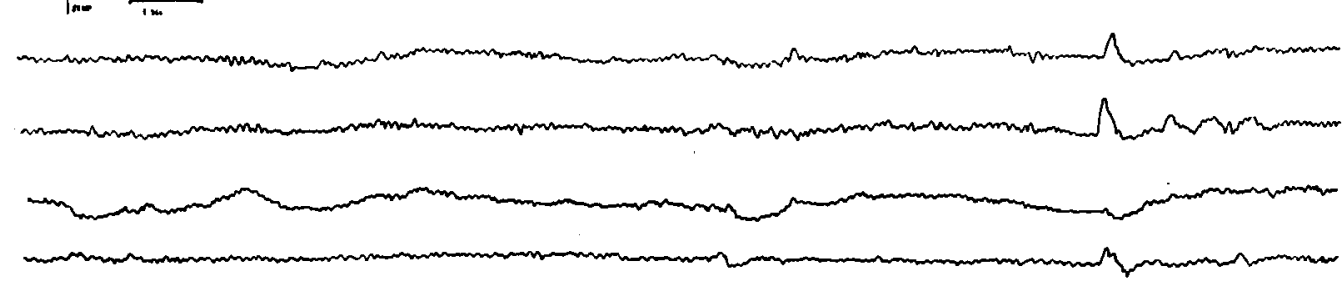

L. P.

R. P.

I. 0 .

R. 0 .

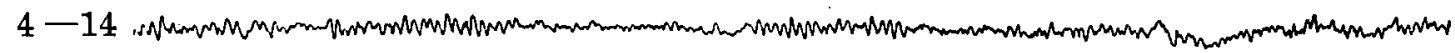

3-13 m.Mp

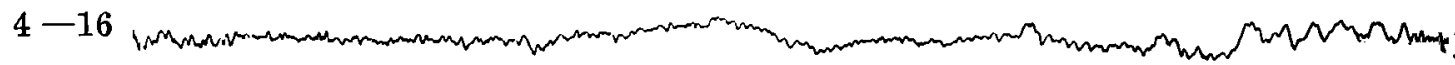

3-15

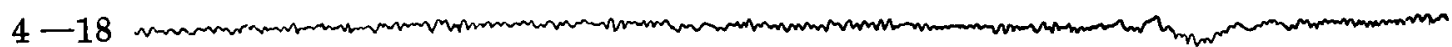

6-12

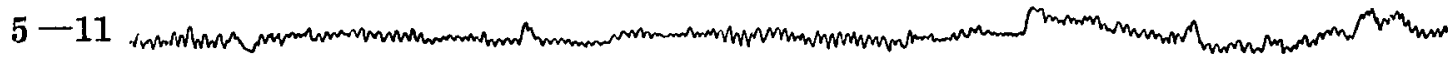


困(2) $18 \quad 1-15$

$2-16$

$1-17$

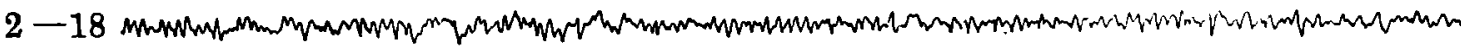

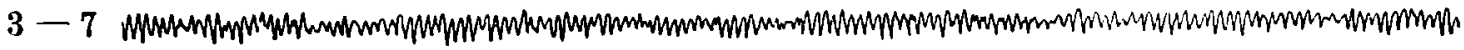

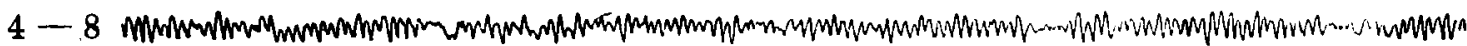

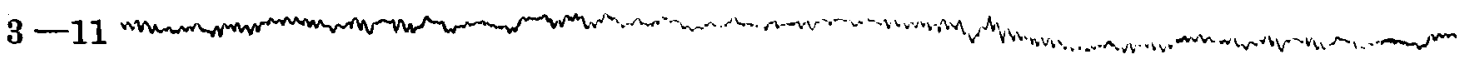

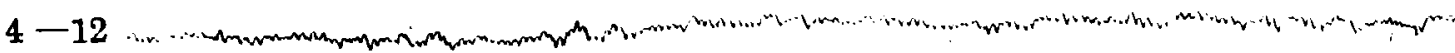

図(2) $191-3$

$2-4$

$3-5$

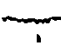

$4-6$

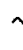

$5-7$

$6-8$

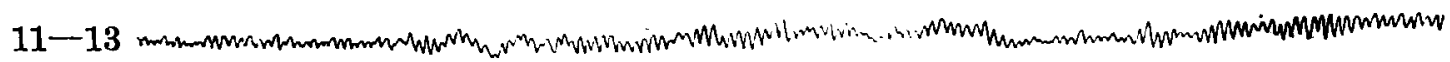

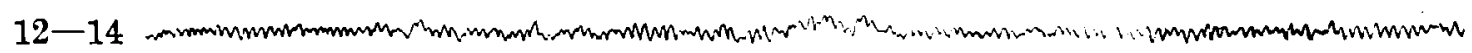

园(2)20 $1-9 \quad$ N

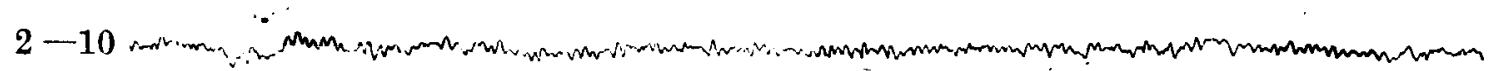
$11-9$ $12-10$ m.m.

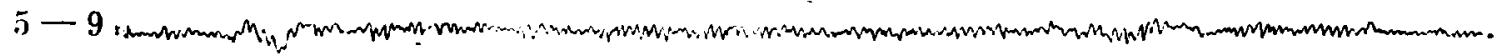
6-10

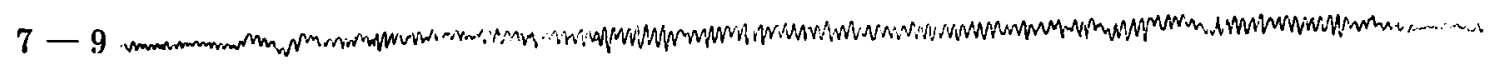
8-10 -

园(2)21 4-10 A

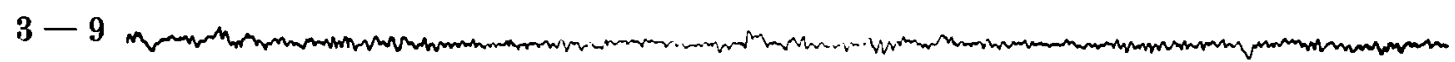
$14-10$

$13-9$

16-10 Vר $15-9$

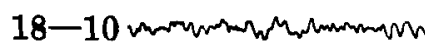

17- 9 a 


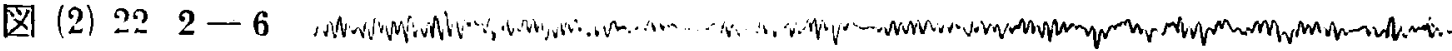

$1-5$ 2.

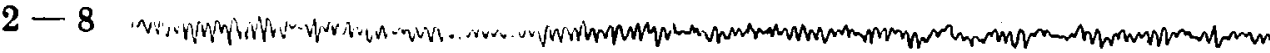

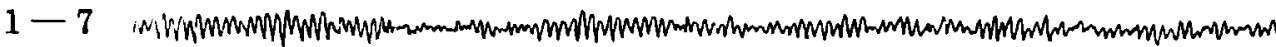

$2-12$

$1-11$

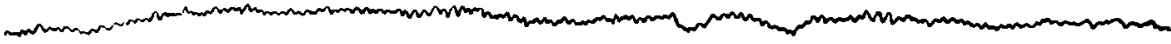

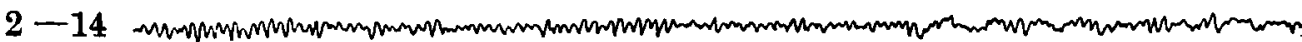

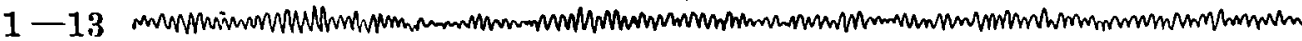

网 (2) $23 \quad 11-17$

$12-18$

$13-15$

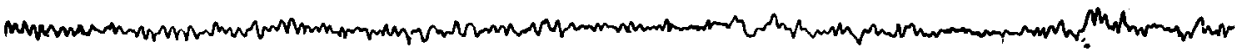

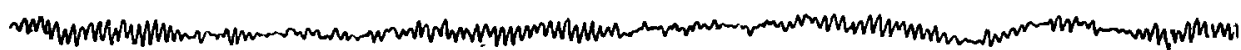

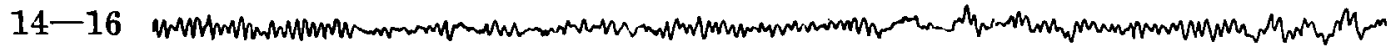

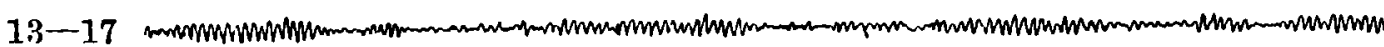

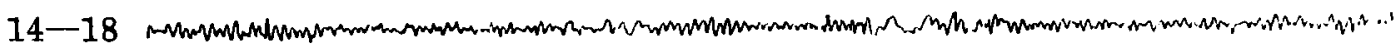

15-17

16-18 - 18

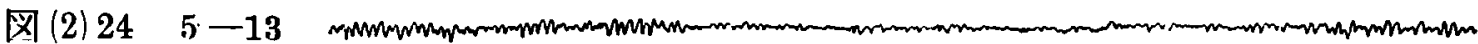

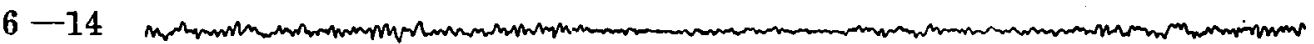

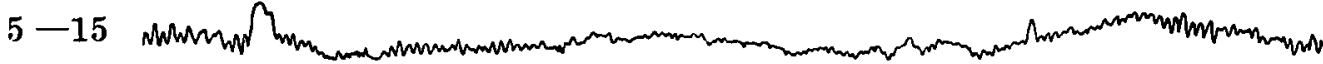

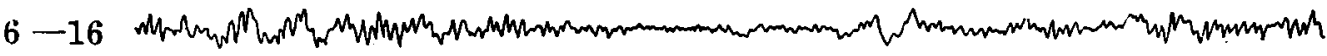

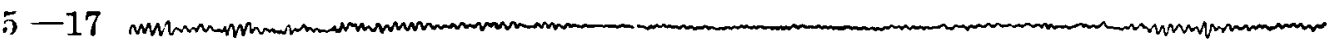

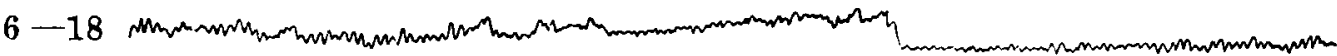

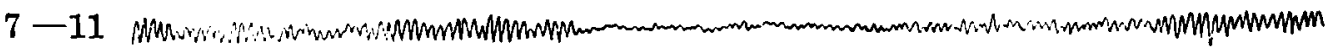

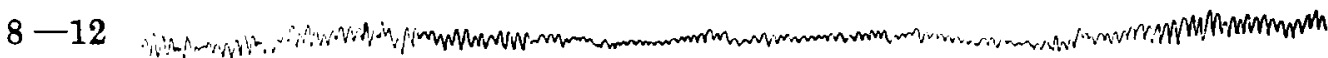

図 (2) $258-14$

$7-13$

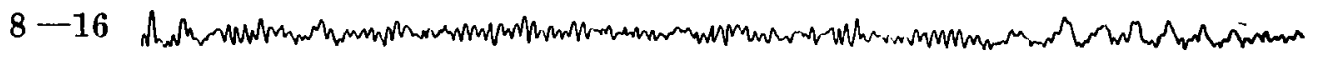

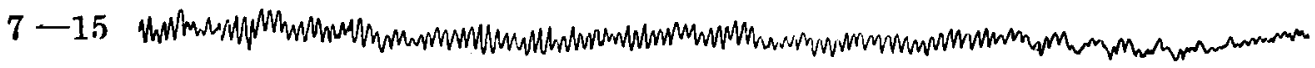

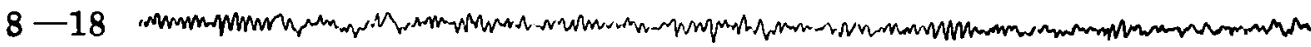

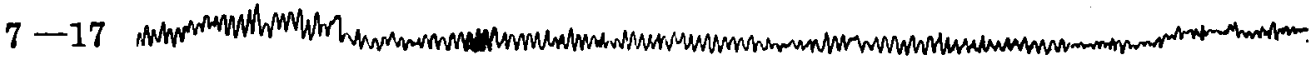

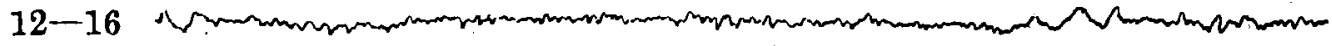

$11-15$

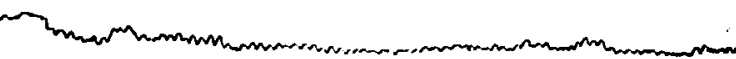




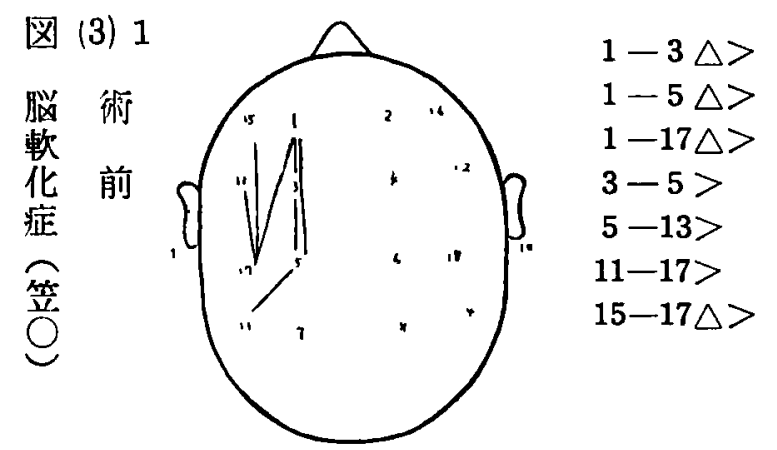

17 (postcentralis) の部を中心に病巢が あると思われる。

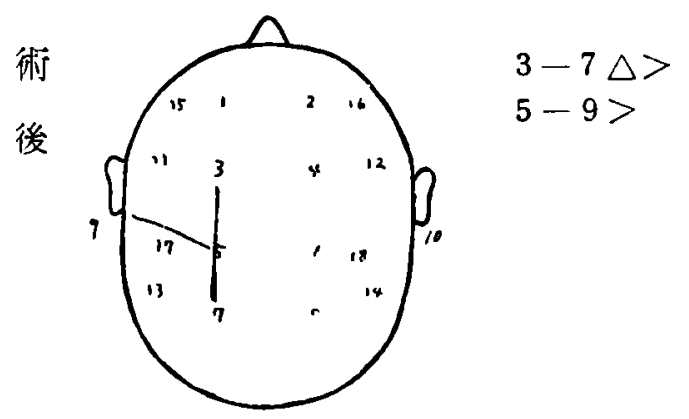

5 (parietal) の部に尚軽度に病茨が 存在すると思われる。

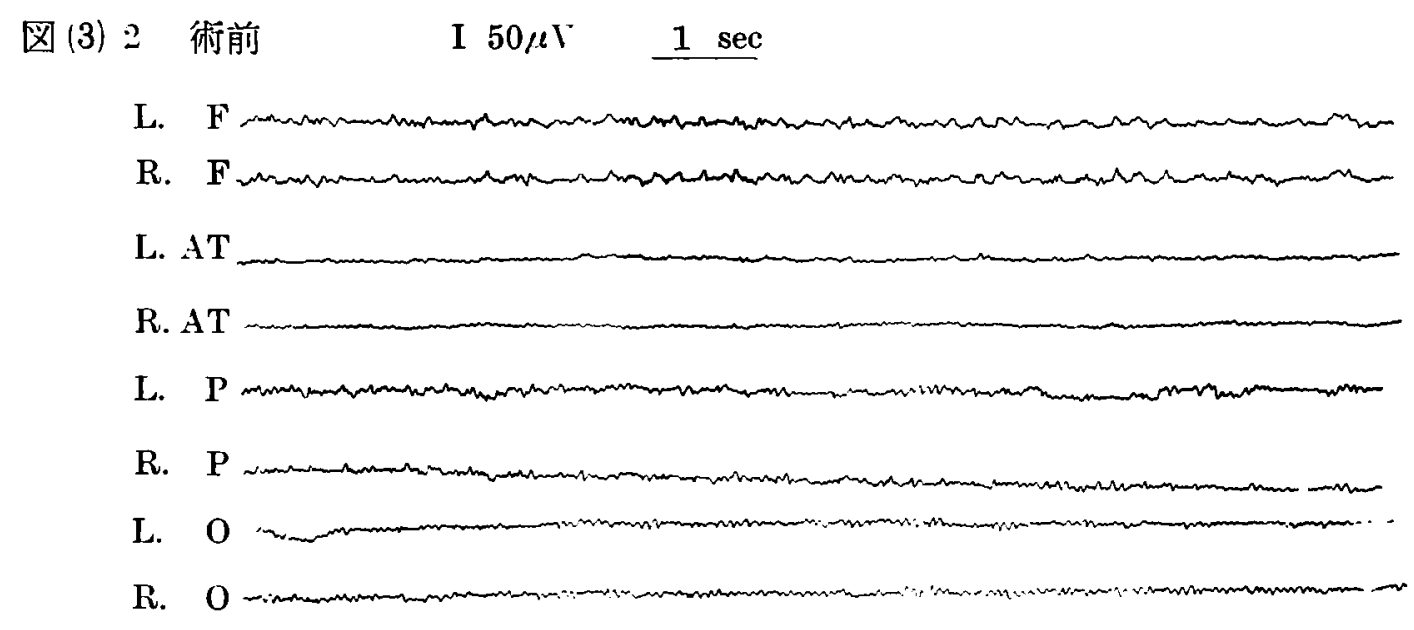

図(3) $3 \quad 1-3$

$$
\begin{aligned}
& 2-4 \\
& 1-5 \\
& 2-6 \\
& 3-5 \\
& 4-6 \\
& 6-14 \\
& 5-13
\end{aligned}
$$

図 (3) $4 \quad 12-18$

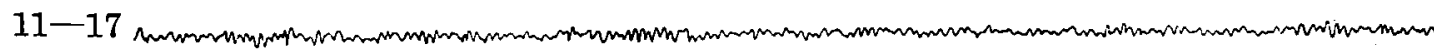

$2-18$

$1-17$

$16-18$

$15-17$

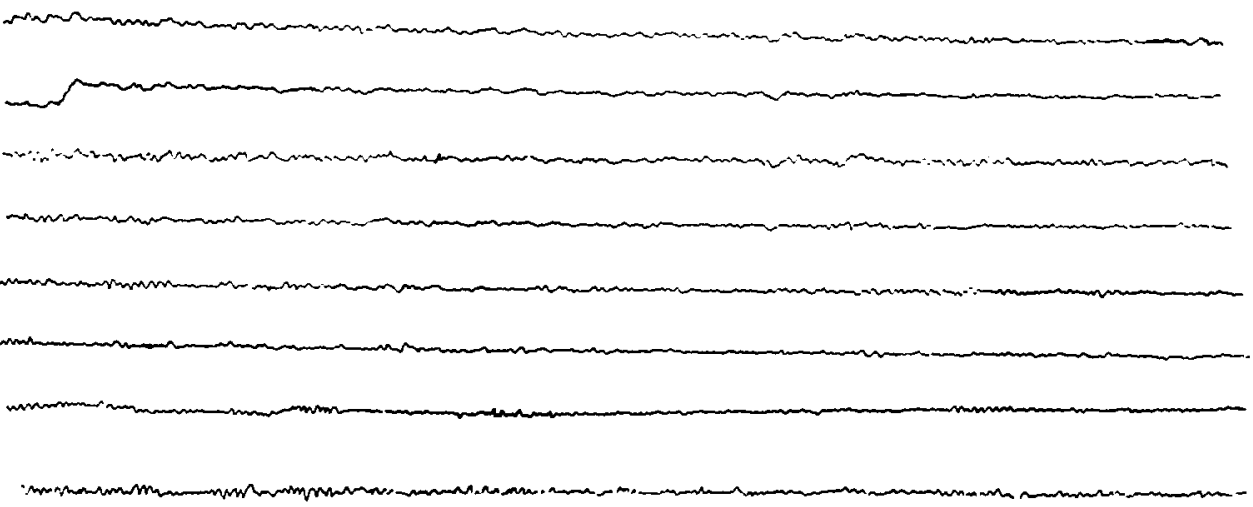

$$
15-17
$$



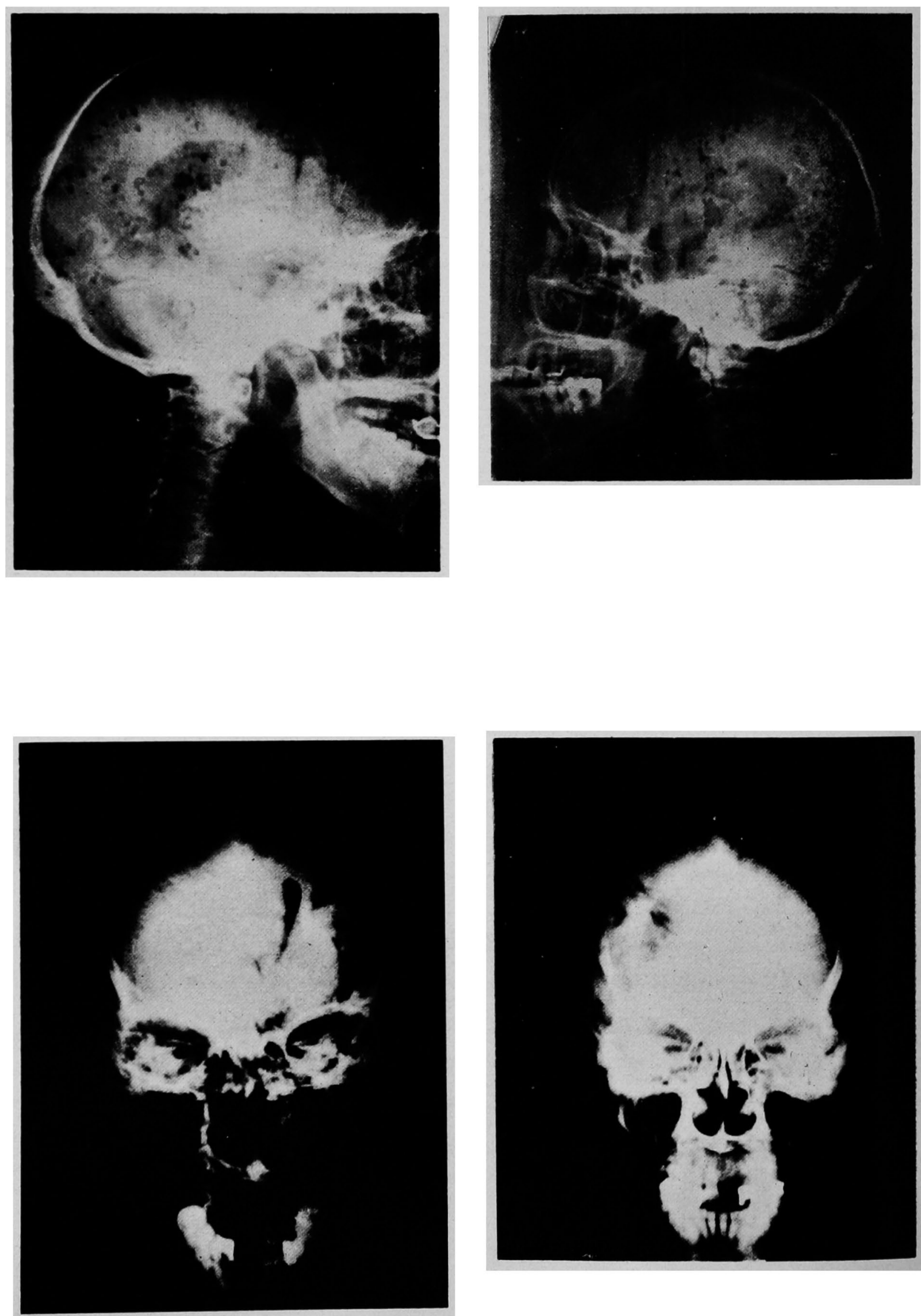
図 (3) 5

L. F.

1 1.-

R. F.

L. ANT. T.

R. ANT. T

L. P.

R. P.

L. 0 .

R. 0 .

困(3) $6 \quad 5-9$

$6-10$

$3-7$

$4-8$

第 2 核はエンドテリオームの例である，左 側半身麻㿎を主培とし，右前頭，側頭部の皮質 下飞存する鵎卵大の腫場を剔除して全治せし めた．脳波所見は術前飞招いては，3〜4 サ1 クル，6〜7サイクルの徐波を呈していたが， 術後の脳波は極めて好転しており，8サイク Nの $\boldsymbol{\alpha}$ 波と，極めて部分的飞 7 サイクルの徐 波が見られるのみである。.この 7 サイクルの 徐波は術後の部分的な浮腫のためのるのと括 るわれる.

第 3 忷山脳軟化症の 1 例である，失瑟，抒 統性の頭痛を主培とし，左中大脳動脈のスパ スムスによる脳粎化症と診断した。 左側内頸 動脈の動脈周囲交感神経切除, 左側頸動脈越 摘出, 左側上頸部交感神経節切除術を行い, 症状の好転をみた。

脳波所見は術前 6 サイクルの徐波を局所的 飞呈していたが，術後飞括いては殆ど消失し て抢り，著しく好転している。

\section{第 5 章 総括並ひに考按}

私はまつ脳腫境その他の患者の脳波検査を 行うに先立ち，あらわれる徐波の週期の範囲 を確実にたしかめんがため，予俑害験として 一側頭蓋内にラミナリアを扫入し，動物実娩 を試みた。 その結果腫場そのものによる䋞波
は3〜4〜5 サイクルの徐波であり，これが基 本型であることを知つた。 しかして，とれに かさなり同側飞も反対側飞も広範䁌にわたり 6〜7サイクルの徐波がみられるが，これは浮 腫を意味するものであることがわかつた。

次で脳腫煌, 脳軟化症, 脳挫傷合計 30 例飞 おいてエアード氏法による脳波検査を行つた ところ，局在決定可能であつたものは脳下垂 体部腫㳻及び松果腺腫輬の 6 例を除く 24 例す なわち80\%に括いて局在決定が可能であつた。 これらを除けば $100 \%$ \%扔いて判定可能であ り，また全例，的中していたことが手術所見 により確められた。

脳下垂体部の腫埸及び松果腺腫煬では全例 に括いて局在決定ができなかつたのは，その 位置からいつても，腫堭の性状からいつても 当然であるといえよう。

術後に括いては庫場が完全に剔出されて跕 床状の好転したものに拓いては買常波が消失 して脳波は正常に復している。

以上の如く，エアード氏法による双極多極 同時誘導方式による脳波検查は通常の単極誘 導方式比し，極めて優秀で脳下垂体部のご とき正中線上にある堹煌を除けば $100 \%$ に的 中し，乙か子䫓监渓上飞投射して，的碓なる 
位滥を亦すことができる。

脳波に影響を及ぼす範囲は，頭皮上に招い て電極の周囲より径 3〜6cm といわれている が，6cm 位はなれると殆ど零であるうとされ ている.しか子頭蓋をと括して記録された脸 波は，皮質上の電気活動の全部ではなく，直 接皮質より誘導した場合の電圧の $1 / 3 \sim 1 / 5$ と いわれている。 また人によつては 1/2〜1/616), Walter'6) は1/15〜1/60 といつている。

従つて頭蓋上よりの脳波の記録を正確なも のにするためには，できるだけ頭部を細分し て誘導を行うことが必要である。このことか らも本法は単極誘導にまさることが首肯され る.

ただ本法の唯一の欠点としてあげられるこ とは，本法では一記録に一側36誘導，すなわ ち両側72誘導を必要とするので長時間を要し， また多数の䉓極を刺入せねばならぬので余り 年少のbのには不可能なことである.

多数例の検査によれば10才以下の子供は検 査不能であるが，12才以上になればおおむ标 本法により記録し㭘査ができるとされている。 また本法の判定に際して，ある時は高電圧の 側を劾側とし，ある時は低電压の側を将側と みなすという一見称盾したことが生じて米る という欠点があるが, Aird ${ }^{(5)}$ はこのことにつ

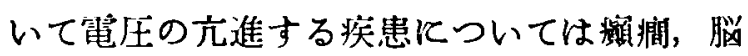
腫境をあげて括り，電压の低下する疾患とし ては退行性变性を起す疾患をあげている。

しかしこれとても決定的なすのではなく， 種々の問題もあるが，要するに記録した全体 の脳波所見よりみ秃ば，その誘導数が多いの で自ら病側が判定されてきて判断に苦しむよ うな場合は少い。

ここで注意を払うべきことは脳腫場組織が 積極的に異常波を発生するるのでは決してな
く，異常波の発生はあくまで間接的なもので ある点である．3〜 5サイクルの徐波す腫煬組 織から出るすのでなく，その周辺の脳細胞よ り出るるのである，従つて，たと光同じ部位， 同じ大きさの腫瘍でもその発育速度や時間的 因子により周辺の脳組織の5ける影響が異な り，相当異つた脳波所見を呈するすのである. また本法による治㙩效果の判定も臨床所見と よく一致して括り，十分価值あるものと思わ れる。

\section{第6 章 結 論}

以上, 脳腫境, 脳㳄化症, 脳挫傷患者 30 例 を対象としてェアード氏法により脳波検査を 行い次の結論を得た.

（1）本法飞よる崞所診断成縝は，睬下垂体 部等正中線上の腫激を除けぼ $100 \%$ \%゙，的中 洋も100 \%ななことを手術所見により確める ことができた。

（2）術後,脳腫瑒を'完全に剔出し，臨床症状 の好転したものでは脳波も正常となり，治療 效果の判定にも極めて洒值あることを知つた。

(3) 䑩腫堵飞打ける基本的な異常波は，3 〜4〜5サイクルの徐波であつて，6〜7サイク ルの徐波は脳浮腫礼よるすのであることを奏 験的に確めた。

（4）本法は脳腫㰾，脳軟化症，脳挫傷等の

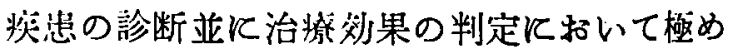
て価伯ある方法である。

稿を終るに臨み，終始御懇篤なる御指導と御校闑 を赐つた，恩師阵内教授に衰心より感謝の意を表方。 又種々御助言を睗つた敨室の沼本博士业化奥村君に 深謝する。

（文献は第 3 編に颃いて一括記栈するため，本編 とおいては省略する.) 
Ist Department of Surgery Okayama University Medical School

(Director : Prof. D. Jinnai)

\section{An Electroencephalographic Study on Various Diseases by Aird's Method.}

\section{Part II. The electroencephalography in the brain tumor and other few brain disease by Aird's method.}

By

\section{Takashi Inagaki}

Thirty cases of brain tumors, encephalomzlacia and brain contusion were investigated by Aird's method.

(1) The fact that the result of diagnosis localizing the lesion by this method was correct at $100 \%$ of all cases except the midline tumors such as hypophyseal tumors, was ascertained by operation.

(2) After the operation, the cases, in which the-tumor was completely excised and clinical symptoms recovered, presented normal encephalogram. Therefure we have known, that it excellent value for judgement of the effect of therapy.

(3) It is clarified experimentally, that the basic abnormal waves in brain tumors consist slow waves with $3-4-5$ cycles, and the slow waves with $6-7$ cycles are caused by brain swelling.

(4) This method is extremely valuable for the diagnosis and the judgement of the effect of therapy of brain tumors, encephalomalacia and brain contusion etc. 